\title{
The Pharmaceutical Availability of Gambier Leaves Bioactive Fraction Coated Tablet in Simulated Human Body Fluids
}

\author{
Ketersediaan Farmasi Tablet Salut Selaput Fraksi Bioaktif \\ Daun Gambir di Simulasi Cairan Tubuh Manusia
}

\author{
Indah Sulistyowati, Nanang Yunarto, Nurul Aini, Kelik M Arifin \\ Center for Research on Biomedic and Basic Health Technology \\ National Institute of Health Research and Development, Jakarta, Indonesia \\ *E-mail: indahsulistyowati26@gmail.com
}

\begin{abstract}
The widespread usage of traditional medicine either in the developed or developing countries, makes traditional medicine requirements become a major concern in terms of assuring the safety and effectiveness of treatment. WHO suggested dissolution study to support traditional medicine clinical trials. The catechins from gambier could reduce atherosclerotic lesions case caused by elevated levels of cholesterol, LDL, and triglycerides. Catechin is hygroscopic that becoming unstable. Raising the stability, gambier is made to a coated tablet. This study aimed to determine the condition of gambier leaves bioactive fraction coated tablet in simulated human body fluids through an in vitro testing using dissolution tester. Three formulations coated tablet with different coating percentage had been tested using dissolution tester apparatus. The test was conducted in water, acid, and buffer as dissolution medium to generate the dissolution profile. Tablet evaluation showed that the three formulations dissolved $71.25 \% \pm 6.26$ to $91.05 \% \pm 3.05$ in the water, acid, and buffer dissolution medium. The gambier leaves bioactive fraction coated tablet had more than $70 \%$ pharmaceutical availability in simulated human body fluids.
\end{abstract}

Keywords: Catechin; Coated tablet; Dissolution test; Gambier leaves bioactive fraction.

\begin{abstract}
Abstrak
Penggunaan obat tradisional secara luas di negara-negara maju maupun berkembang menjadikan pentingnya penetapan syarat obat tradisional untuk keamanan dan keefektifan pengobatan. WHO memasukkan parameter uji disolusi sebagai data yang diperlukan untuk menunjang uji klinis obat tradisional. Katekin dari gambir berkhasiat mengurangi lesi aterosklerosis pada kasus peningkatan kadar kolesterol, LDL, dan trigliserida. Katekin bersifat higroskopis sehingga untuk meningkatkan kestabilannya dibuat tablet salut selaput. Penelitian ini bertujuan untuk mengetahui kelarutan tablet salut selaput fraksi bioaktif daun gambir di dalam cairan tubuh manusia dengan alat uji disolusi. Tiga tablet dengan variasi prosentase penyalut diuji kelarutannya dengan menggunakan alat uji disolusi. Uji disolusi dilakukan dalam media disolusi air, asam, dan buffer untuk mengetahui profil disolusinya pada interval waktu tertentu. Hasil uji disolusi menunjukkan kelarutan katekin

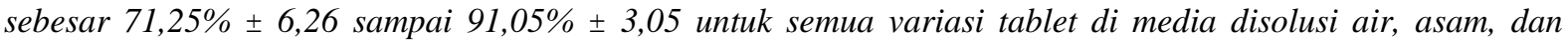
buffer. Tablet salut selaput fraksi bioaktif daun gambir mempunyai nilai ketersediaan farmasi lebih dari $70 \%$ di dalam simulasi cairan tubuh manusia.
\end{abstract}

Kata kunci: Fraksi bioaktif daun gambir ; Katekin; Tablet salut selaput; Uji disolusi. 


\section{INTRODUCTION}

According to World Health Organization, more than $50 \%$ population of a country use traditional medicine as medicaments for threating short and chronic ailments, termed as complementary medicine. ${ }^{1}$ The acceptability of traditional medicine is increasing now a day due to their affordability, effectiveness, and less toxicities. ${ }^{2}$ The medicinal plant's overflow availability and affordable price underlie studies of medicine raw material. ${ }^{3}$

Recent studies showed Indonesian pharmaceutical industries imported more than $90 \%$ medicine raw material for chemical medicine, worth USD 959 million. ${ }^{4,5}$ Optimizing the potential of medicinal plants is expected to reduce the raw material import dependency also stabilizing the price and availability. ${ }^{3}$

Indonesia as one of developing countries has very potential biodiversity to be developed, among others medicinal plants. Indonesian Ministry of Trade reported in 2013, Indonesia exported traditional medicine worth $\$ 23,44$ million. $^{6}$ Gambier is one of the medicinal plants that can be found in Indonesia and become west Sumatra top export commodities. It dominates almost $90 \%$ gambier source in Indonesia. $^{7}$

Gambier has $35-95 \%$ catechin as the main component that can reduce levels of cholesterol, LDL, triglycerides and increases levels of HDL with $20 \mathrm{mg}$ dose/ 200 g mice weight., Besides catechin, there are epicatechin, procyanidin, gambierin, red catechu, quercetin, and also fat, wax, and alkaloids. ${ }^{10,11}$

Due to the widespread usage of traditional medicine, many pharmaceutical companies produce various traditional medicine formulations inclusive of a tablet. Ensuring the quality, The National Agency of Drug and Food Control requires some physical and chemical parameters to be fulfilled. WHO suggested dissolution studies to support clinical trials of herbal products. $^{12}$
Bioavailability is one of the tablet quality requirement to assure the tablet gives therapeutic effects. The bioavailability test as an in vivo performance can be predicted through in vitro testing using dissolution tester. The dissolution test will show the tablet pharmaceutical availability that represents the amount of dissolved active substances. The higher active substances dissolved, the higher active substances absorbed in stomach and intestines to give therapeutic effects. ${ }^{13}$

Catechin is hygroscopic due to its many hydroxyls. ${ }^{14}$ Furthermore, excessive ultraviolet radiation including high influence rate and long period radiation decreased the level of total catechin. ${ }^{15}$ The instability of catechin is proven that after six weeks, catechin in gambier mouthwash decreased 5,06\%. ${ }^{16}$ Increasing the stability, gambier requires to be fractionated and the tablets require to be coated. While to ascertain the efficacy, the tablets require dissolution test.

Gambier leaves extract was fractionated with ethyl acetate due to Kassim found that the highest catechin was in ethyl acetate than either in methanol or in hot water. ${ }^{17}$ Gambier tablet was formulated into $4 \%, 6 \%$, and $8 \%$ weight gain accordance to Subburayalu, that opadry AMB as a protective layer found to be stable at $4 \%, 6 \%$, and $8 \%$ of weight gain. ${ }^{18}$

Dissolution profile is the time required for tablets to dissolve in the dissolution medium. The dissolution profile differences occur due to the formulas. The aim of this study is to determine the dissolution profile of three different coating percentage tablets in simulated human body fluids: water, acid, and buffer.

The dissolution test was carried out in three dissolution medium that represents a place of drugs absorption. Water represents major human body fluids, acid medium $\mathrm{pH}$ 1.2 represents gastric fluids, and buffer medium $\mathrm{pH} \quad 6.8$ represents intestinal fluids. ${ }^{19}$ The tablets were tested in a wide 
physiological $\mathrm{pH}$ range from 1.2 to 7.8 to determine the solubility characteristic. ${ }^{2}$

\section{METHOD}

This study was conducted in Pharmacy Laboratory, Center for Research on Biomedic and Basic Health Technology, National Institute of Health Research and Development. Three different coating percentage tablets of gambier leave bioactive fraction had been tested using dissolution tester apparatus. The test was conducted in three simulated human body fluids (without enzyme): water, acid, and buffer. Dissolved catechin in dissolution medium was analyzed using high performance liquid chromatography (HPLC).

\section{Equipment and materials}

The equipment were: analytical balance (Mettler Toledo), dissolution tester (Hanson Vision G2 Elite), high performance liquid chromatography (Waters Alliance 2695).

The materials were: catechin reference (Sigma Aldrich), methanol LC grade (Merck), trifluoroacetic acid (Merck), acetonitrile LC grade (Merck), formic acid (Merck), universal $\mathrm{pH}$ tape measurement (Merck), chloride acid 32\% (Merck), potassium dihydrogen phosphate (Merck), sodium chloride (Merck), sodium hydroxide (Merck), distilled water, microcrystalin cellulose (Avicel PH 102), polyvynyl pyrolidone (PVP Kollidon K30), Magnesium stearate, sodium starch glycolate (Primojel), talc, aerosil, and opadry AMB white (Colorcon).

\section{Samples}

The samples were: core tablet of gambier bioactive fraction, tablet A: $4 \%$ weight gain coated tablet of gambier leaves bioactive fraction, tablet $\mathrm{B}: 6 \%$ weight gain coated tablet of gambier leaves bioactive fraction, and tablet C: $8 \%$ weight gain coated tablet of gambier leaves bioactive fraction.

\section{Gambier leaves extract fractionation}

Amount of gambier leaves extract was fractionated with ethyl acetate. The fractionation was preceded by 6-hour maceration. Percolation is afterward. The fractionation was done up to limpid fraction. ${ }^{17}$

\section{Tablet coating}

The core tablet of gambier bioactive fraction was coated with opadry AMB white suspension. The tablet coating was conducted with a round coating pan that rolling stable. The opadry AMB suspension was sprayed with spray gun into the pan contained the core tablet. Whereas in front of the pan, there is a hot air blower that blown a hot air into the pan to dry up the tablet. The air inside the pan was suctioned out with vacuum exhaust. The coating was done up to $4 \%, 6 \%$, and $8 \%$ of weight gain. ${ }^{20}$

\section{Simulated gastric fluid pH 1.2}

$2.0 \mathrm{~g}$ of sodium chloride dissolved in $7.0 \mathrm{ml}$ of chloride acid $32 \%$, diluted with distilled water up to $1000 \mathrm{ml} .^{19}$

\section{Simulated intestinal fluid pH 6.8}

$8.96 \mathrm{~g}$ of sodium hydroxide was added into $68.05 \mathrm{~g}$ potassium dihydrogen phosphate then dilute with distilled water up to $1000 \mathrm{ml}^{19}$

\section{Dissolution studies}

Dissolution studies were carried out in $900 \mathrm{ml}$, in each of distilled water, simulated gastric fluid $\mathrm{pH} 1.2$, and simulated intestinal fluid $\mathrm{pH} 6.8$ using Hanson Vision G2 Elite type II (paddle) dissolution test apparatus. The dissolution medium was maintained at $37 \pm 0.5^{\circ} \mathrm{C}$ and a speed of $100 \mathrm{rpm}$ paddle stirrer. A $10 \mathrm{ml}$ aliquot was withdrawn at different time intervals $(15,30,45$, and 60 minutes), filtered, and replaced with $10 \mathrm{ml}$ of fresh dissolution medium to maintain a constant volume. The aliquot was analyzed using high performance liquid chromatography. ${ }^{21}$ 


\section{Catechin assay}

The aliquot was analyzed by high performance liquid chromatography that equipped with a 4.6 x $150 \mathrm{~mm}$ Sun Fire column and PDA detector. Catechin was detected at $280 \mathrm{~nm}$ with $0.45 \mathrm{ml} / \mathrm{min}$ flow rate and $1.0 \mu \mathrm{L}$ volume of injection. The method is using $0.03 \%$ trifluoroacetic acid in acetonitrile:distilled water (5:95) as mobile phase $\mathrm{A}$ and $0.1 \%$ trifluoroacetic acid in acetonitrile as mobile phase B with gradient condition: $0-4$ minutes $(100 \% \mathrm{~A})$, 4-20 minutes $(71.5 \mathrm{~A} ; 28.5 \mathrm{~B})$ and $20-30$ minutes $(100 \% \mathrm{~B}){ }^{9}$

\section{RESULT AND DISCUSSION}

Dissolution is a movement of particles from a solid into a solvent (medium) where the particles become a solution. The dissolution studies show the tablets ability to release active substances inside that dissolve in gastric or intestinal fluids. The dissolution test will confirm disintegration time due to disintegration time simply indicates the time it takes for the tablet to disintegrate into small particles, without giving assurance that the tablet is able to release the active substances inside. ${ }^{22}$ Tablet with fast disintegration time is not necessarily high soluble that the dissolution test is required. The dissolution test describes the release of the drug into a bioavailability form. ${ }^{23}$

The dissolution results as the means of percents dissolved versus time for core tablet of gambier bioactive fraction, tablet $\mathrm{A}$, tablet $\mathrm{B}$, and tablet $\mathrm{C}$ coated tablet of gambier leaves bioactive fraction are given in Table 1. The dissolution profile of all samples in water, acid, and buffer dissolution medium is given in figure 2,3 , and 4 respectively.

The chromatogram in figure 1 , showed catechin reference and dissolved catechin peak at thirteenth minutes of retention time. The retention time similarity between catechin reference and dissolved substances in dissolution medium confirmed that the dissolved substance is catechin.

Table 1. Dissolution Test Result

\begin{tabular}{|c|c|c|c|c|c|}
\hline \multirow{2}{*}{\multicolumn{2}{|c|}{$\begin{array}{c}\text { Medium } \\
\text { and } \\
\text { Time }\end{array}$}} & \multicolumn{4}{|c|}{ Dissolution Test Result (\%) } \\
\hline & & Core Tablet & Tablet A & Tablet B & Tablet C \\
\hline \multirow{4}{*}{ Water } & $15^{\prime}$ & $84.74 \pm 3.97$ & $87.43 \pm 4.36$ & $91.05 \pm 3.05$ & $90.14 \pm 2.25$ \\
\hline & $30^{\prime}$ & $86.93 \pm 3.92$ & $89.92 \pm 2.35$ & $87.97 \pm 5.42$ & $87.51 \pm 2.43$ \\
\hline & $45^{\prime}$ & $87.49 \pm 5.28$ & $89.25 \pm 2.53$ & $90.71 \pm 0.83$ & $86.76 \pm 4.40$ \\
\hline & $60^{\prime}$ & $88.15 \pm 2.85$ & $86.96 \pm 1.19$ & $88.27 \pm 0.80$ & $85.36 \pm 4.48$ \\
\hline \multirow{4}{*}{$\begin{array}{c}\text { Acid } \\
\text { pH } 1.2\end{array}$} & $15^{\prime}$ & $86.95 \pm 6.49$ & $86.08 \pm 3.61$ & $90.68 \pm 8.58$ & $89.69 \pm 8.23$ \\
\hline & $30^{\prime}$ & $84.09 \pm 4.66$ & $92.54 \pm 2.02$ & $93.03 \pm 2.39$ & $86.73 \pm 5.25$ \\
\hline & $45^{\prime}$ & $83.47 \pm 5.78$ & $80.69 \pm 2.95$ & $88.55 \pm 5.84$ & $97.39 \pm 2.28$ \\
\hline & $60^{\prime}$ & $94.42 \pm 2.42$ & $91.65 \pm 6.62$ & $92.68 \pm 3.42$ & $93.37 \pm 2.94$ \\
\hline \multirow{4}{*}{$\begin{array}{l}\text { Buffer } \\
\text { pH } 6.8\end{array}$} & $15^{\prime}$ & $83.62 \pm 5.15$ & $82.16 \pm 4.50$ & $79.66 \pm 2.77$ & $71.25 \pm 6.26$ \\
\hline & $30^{\prime}$ & $73.43 \pm 2.40$ & $67.39 \pm 2.66$ & $70.96 \pm 1.32$ & $65.57 \pm 3.31$ \\
\hline & $45^{\prime}$ & $60.74 \pm 2.34$ & $55.97 \pm 1.61$ & $55.46 \pm 3.65$ & $54.26 \pm 3.01$ \\
\hline & $60^{\prime}$ & $56.79 \pm 1.25$ & $48.77 \pm 2.53$ & $50.31 \pm 3.94$ & $49.66 \pm 1.30$ \\
\hline
\end{tabular}


Catechin is poorly soluble in water but dissolves easily in hot water. ${ }^{17,24}$ Dissolution medium with $37^{\circ} \mathrm{C}$ temperature has enhanced catechin solubility in water. Catechin in the core and coated tablets dissolved $84.74 \% \pm 3.97$ to $91.05 \% \pm 3.05$ (Table 1) in water at the first fifteen minutes.

In water dissolution medium, tablet $\mathrm{A}$, $\mathrm{B}$, and $\mathrm{C}$ had nearly the same profile dissolution with core tablet of gambier leaves bioactive fraction (Figure 2). All samples dissolved significantly at the first fifteen minutes and dissolved stably up to the sixtieth minute. According to the data, tablet coating is not affecting drugs release accordance to Patel. ${ }^{25}$

Dissolved catechin in water dissolution medium showed in the first fifteen minutes, the core tablet and tablet $\mathrm{A}, \mathrm{B}$, and $\mathrm{C}$ dissolved more than $80 \%$ but decreased slightly in the last sixty minutes (figure 2). The reduction of catechin in the dissolution medium is due to there had been a maximum dissolution in the two first time interval. The dissolution medium addition will cause dilution. ${ }^{26}$

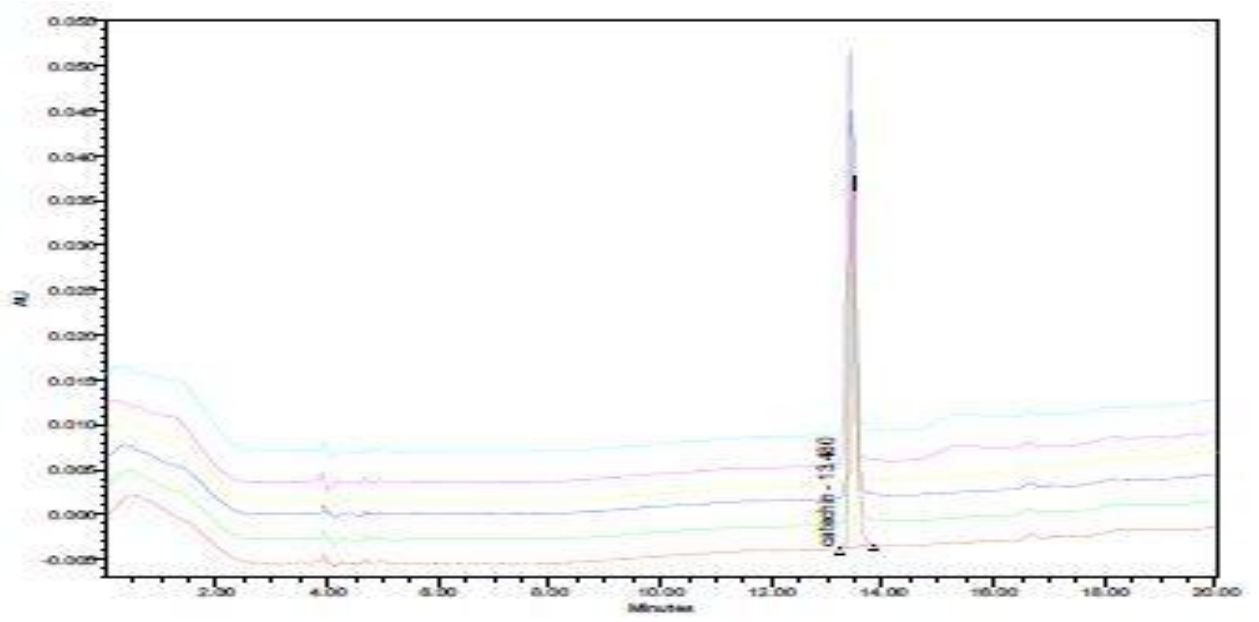

Figure 1. HPLC chromatogram of catechin reference and dissolution sample

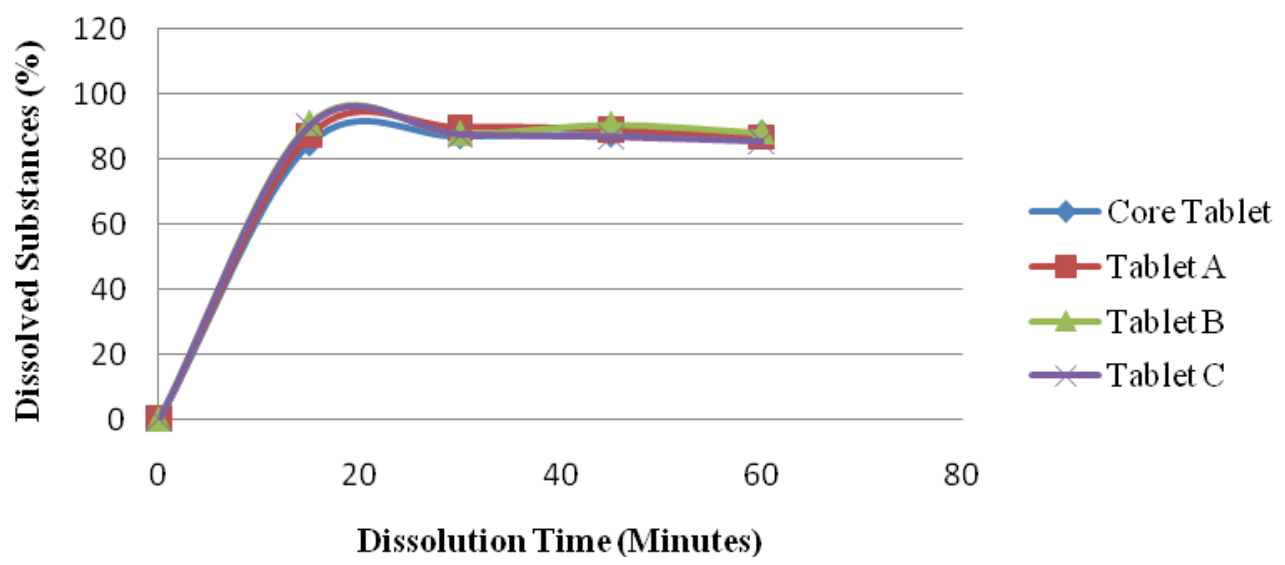

Figure 2. Dissolution profile in water 
Active substances in acid dissolution medium produce fluctuate dissolution profile chart (Figure 3). The fluctuation is affected by type of apparatus (paddle or basket), stirring rate, dissolution medium temperature tolerance, as well as withdrawing and substituting dissolution medium. $^{2}$

Core tablet, tablet A, B, and C dissolved more than $80 \%$ (table 1) in the first fifteen minutes due to catechin has a high reactivity in acid physiological $\mathrm{pH} .{ }^{25}$ Percentage of coating had not shown containment of active substance, precisely because tablet $\mathrm{B}$ with $6 \%$ of coating resulted dissolved catechin greater than core tablet. Coating only affects the physical and chemical stability of the tablet. $^{25}$

Core tablet, Tablet A, B, and C in buffer medium gave different dissolution profiles (Figure 4) than in water and acid medium. In the first fifteen minutes, dissolution occurs in a range of $71.25 \% \pm$ 6.26 to $83.62 \% \pm 5.15$ (Table 1 ). In the next three interval times: 30,45 , and 60 minutes the dissolution decreased consecutively, in a range $56.79 \% \pm 1.25$ to $49.66 \% \pm 1.30$ (Table 1$)$.

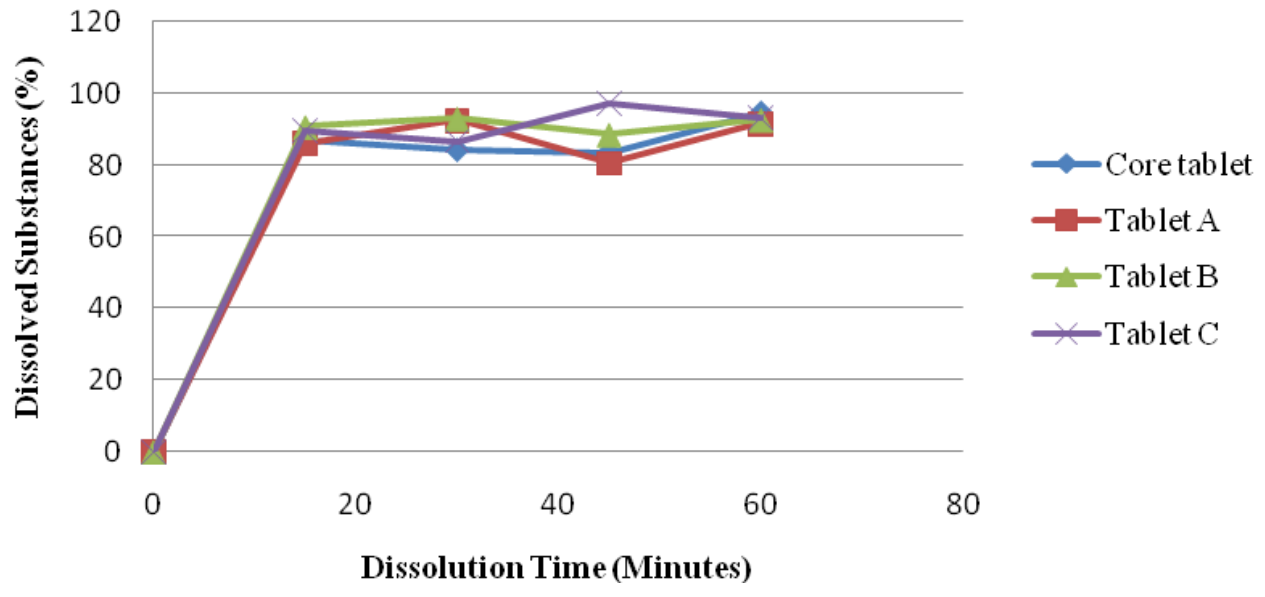

Figure 3. Dissolution profile in acid

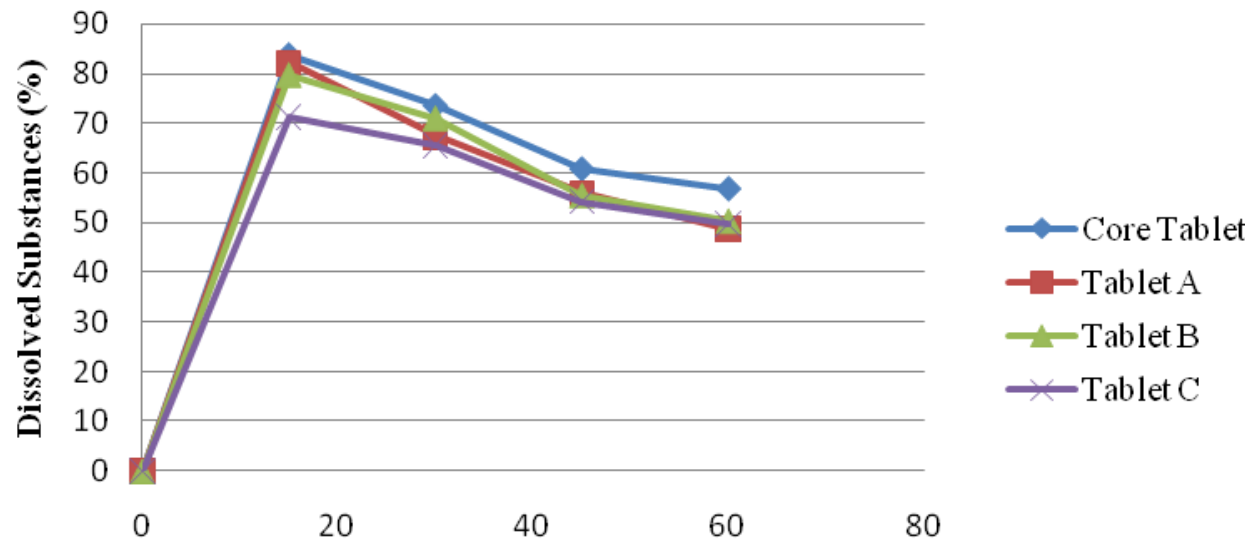

Dissolution Time (Minutes)

Figure 4. Dissolution profile in buffer 
The decreased level of dissolved catechin is affected by the tablet excipient, polyvinyl pyrolydone that can form high viscosity layer around the tablet if it reacts to water (part of buffer dissolution medium). The layer could inhibit releasement of catechin as the active substance into dissolution medium. The containment gave a level decrease. Whereas, catechin in pH 6.9 easily turns into tannic catechu acid. ${ }^{27}$

The lessening of catechin in buffer medium is expected not to affect the effectiveness of treatment because the tablet had already dissolved more than $70 \%$ in water and acid that represent stomach, a place of absorption before intestines. Accordance with the function of the coated tablet that expected to disintegrate in stomach. ${ }^{28}$

The result of dissolution test showed all the tablets had $71.25 \% \pm 6.26$ to $91.05 \% \pm 3.05$ (table 1) pharmaceutical availability in water that represents a major human body fluid, in acid that represents the stomach, and in buffer that represents the intestine.

\section{CONCLUSION}

The gambier leaves bioactive fraction coated tablet had more than $70 \%$ pharmaceutical availability in simulated human body fluids: water, acid, and buffer. A large amount of dissolved catechin is expected to generate effective treatment.

\section{ACKNOWLEDGEMENT}

The authors would like to express their gratitude to Mrs. Dra. Ani Isnawati, M.Kes, Apt as the head of the pharmaceutical laboratory and Mr. Sumardiyanto, MM, Apt as the technology transfer supervisor research and development of PT Actavis Indonesia, for the laboratory facilities supporting.

\section{REFERENCES}

1. World Health Organization. WHO traditional medicine strategy: 2014-2023. Geneva: WHO Press; 2013.

2. Vadlamudi HC, Venkaiah, Malik S, Reddy $\mathrm{H}$, Achari S, Raju P. Dissolution test as a quality control tool for herbal formulationsa comprehensive review. International Journal of Innovative Pharmaceutical Research. 2014;5(1):364-9.

3. Wasito H. Obat tradisional kekayaan Indonesia. Yogyakarta: Graha ilmu; 2011.

4. Mustamu RH. Manajemen rantai pasokan industri farmasi di Indonesia. Jurnal Manajemen dan Kewirausahaan. 2007;9(2):99-105.

5. Dhalimi A. Permasalahan gambir (Uncaria gambir L.) di Sumatera Barat dan alternatif pemecahannya. Perspektif. 2015; 5(1):46-9.

6. Adi, AHB. Pengembangan Agroindustri Gambir di Kabupaten Lima Puluh Kota, Sumatera Barat. Bogor: IPB Press. 2011

7. Pribadi, ER. Pasokan dan permintaan tanaman obat Indonesia serta arah penelitian dan pengembangannya. Perspektif. 2015; 8(1):52-64

8. Amos L. Kandungan katekin gambir sentra produksi di Indonesia. Jurnal Standardisasi. 2010;12(3):149-55.

9. Yunarto N, Elya B, Konadi L. Potensi fraksi etil asetat daun gambir sebagai antihiperlipidemia. Jurnal Kefarmasian Indonesia. 2015;5(1):1-10.

10. Ferdinal N, Nazir N. Phytochemical screening and fractination of gambier (Uncaria gambir). The Journal of Biomaterial Chemistry. 2013;1(1):23-5.

11. Taniguchi S, Kuroda K, Doi K, Inada K, Yoshikado N, Yoneda Y, et al. Evaluation of gambir quality based on quantitative analysis of polyphenolic constituents. Yakugaku Zasshi. 2007;127(8):1291-300.

12. World Health Organization. TDR operational guidance: information needed to support clinical trials of herbal products. Geneva: WHO Press; 2005.

13. Anief M. Farmasetika. Yogyakarta: Gajah Mada University Press. 2007.

14. Kailaku SI, Udin F, Pandji C, Amos. Analisis mutu dan penerimaan konsumen terhadap permen tablet dengan formulasi konsentrasi pengisi, pemanis, dan gambir. Jurnal Pascapanen. 2005;2(1):34-40. 
15. Zheng XQ, Chen H, Du YY, Ye JH, Lu JL, et al. Effect of ultraviolet B irradiation on accumulation of catechins in tea (Camelia sinensis (L) O. Kuntze). African Journal of Biotechnology. 2008;7(18):3283-87.

16. Lucida H, Bakhtiar A, Putri WA. Formulasi sediaan antiseptik mulut dari katekin gambir. Jurnal Sains dan Teknologi Farmasi. 2007;12(1):25-31.

17. Kassim MJ, Hussin MH, Achmad A, Dahon H, Suan TK, Hamdan HS. Determination of total phenol, condensed tannin, flavonoid contents, and antioxidant activity of Uncaria Gambir extract. Majalah Farmasi Indonesia. 2011;22(1):509.

18. Subburayalu R, Kunchithapatham J, Pillappan R, Raja D. Formulation and stabilization of aspirin mini-tablets with the aid of weak acid and moisture protective coating. International Journal for Pharmaceutical Research Scholars. 2013;2(4):42-50.

19. Sinko PJ. Farmasi fisika dan ilmu farmasetika. Ed ke-5. Jakarta: Penerbit Buku Kedokteran EGC; 2012.

20. Pradana R, Chaidir, Anwar E. Formulasi tablet salut teofilin menggunakan eksipien koproses pregelatinisasi pati singkongmetil selulosa sebagai bahan penyalut. Majalah Ilmu Kefarmasian. 2010;7(1):4962.
21. Badan Pengawas Obat dan Makanan. Pedoman uji bioekivalensi. 2005.

22. Stuart AV, Clement Y, Sealy P, Lobenberg R, Jaime LM, Maharaj RG, Maxwell A. Comparing the dissolution profiles of seven metformin formulations in simulated intestinal fluid. Dissolution Technologies. 2015;Feb: 17-21.

23. Saptarini NM and Rusniyanti. Evaluation of content and dissolution profile of generic amoxicillin tablets marketed in Indonesia. International Research Journal of Pharmacy. 2012;3(12):64-6.

24. Bakhtiar R, Gaesari SR, Zaini E. Pembentukan kokristal katekin dengan nikotinamida. Jurnal Farmasi Sains dan Terapan. 2015;2(2):28-32.

25. Patel H, Shah V, Upadhyay U. New pharmaceutical excipients in solid dosage forms. International Journal of Pharmacy and Life Sciences. 2011;2(8):1006-19.

26. Djafar F, Redha F. Karakterisasi dan modifikasi sifat fungsional kayu manis dalam produk pangan. Jurnal Hasil Penelitian Industri. 2012;25(1):18-27.

27. Santoso B, Tampubolon $\mathrm{OH}$, Wijaya A, Pambayun R. Interaksi $\mathrm{pH}$ dan ekstrak gambir pada pembuatan edible film anti bakteri. Agritech. 2014;34(1):8-13.

28. Ansel HC. Pengantar Bentuk Sediaan Farmasi. Ed ke-4. Jakarta: UI Press; 2008. 